\title{
Chromosomal mapping of repetitive DNA in Melipona seminigra merrillae Cockerell, 1919 (Hymenoptera, Apidae, Meliponini)
}

\author{
Ingrid Cândido de Oliveira Barbosa', Carlos Henrique Schneider², \\ Leonardo Gusso Goll ${ }^{3}$, Eliana Feldberg ${ }^{4}$, Gislene Almeida Carvalho-Zilse ${ }^{5}$
}

I Grupo de Pesquisas em Abelhas, Programa de Pós-Graduação em Genética, Conservação e Biologia Evolutiva, Instituto Nacional de Pesquisas da Amazônia, Av. André Araújo 2936, Petrópolis, 69067-375, Manaus, Brazil 2 Laboratório de Pesquisa em Ciências Médicas, Universidade Federal da Integração Latino Americana, Av. Silvio Américo Sasdelli 1842, Itaipu A, 85866-000, Foz do Iguaçu, Brazil 3 Instituto de Natureza e Cultura - INC, R. Primeiro de Maio s/n, Colônia, 69630-000, Benjamin Constant, Brazil 4 Laboratório de Genética Animal, Programa de Pós-Graduação em Genética, Conservação e Biologia Evolutiva, Instituto Nacional de Pesquisas da Amazônia, Av. André Araújo 2936, Petrópolis, 69067-375, Manaus, Brazil 5 Grupo de Pesquisas em Abelhas, Coordenação de Biodiversidade, Instituto Nacional de Pesquisas da Amazônia, Av. André Araújo 2936, Petrópolis, 69067-375, Manaus, Brazil

Corresponding author: Ingrid Cândido de Oliveira Barbosa (ingridcandido.bio@gmail.com)

Academic editor: V. Gokhman | Received 13 July 2020 | Accepted 3 February 2021 | Published 19 March 2021

http://zoobank.org/59006C5D-C9E3-4675-8E72-1701CFAD67C7

Citation: Barbosa ICO, Schneider CH, Goll LG, Feldberg E, Carvalho-Zilse GA (2021) Chromosomal mapping of repetitive DNA in Melipona seminigra merrillae Cockerell, 1919 (Hymenoptera, Apidae, Meliponini). CompCytogen 15(1): 77-87. https://doi.org/10.3897/compcytogen.v15.i1.56430

\begin{abstract}
Melipona Illiger, 1806 is represented by 74 known species of stingless bees, distributed throughout the Neotropical region. Cytogenetically it is the most studied stingless bee genus of the tribe Meliponini. Member species are divided in two groups based on the volume of heterochromatin. This study aim was to analyze the composition and organization of chromatin of the stingless bee subspecies Melipona seminigra merrillae Cockerell, 1919 using classical and molecular cytogenetic techniques, so contributing to a better understanding of the processes of chromosomal changes within the genus. We confirm that M. seminigra merrillae has a chromosome number of $2 \mathrm{n}=22$ and $\mathrm{n}=11$, results that differ from those reported for the genus in the absence of $\mathrm{B}$ chromosomes. The heterochromatic pattern revealed a karyotype composed of chromosomes with a high heterochromatin content, which makes it difficult to visualize the centromere. Silver nitrate impregnation (Ag-NOR) showed transcriptionally active sites on the second chromosomal pair. Staining of base-specific fluorophores DAPI-CMA 3 indicated a homogeneous
\end{abstract}

Copyright I. C. de Oliveira Barbosa et al. This is an open access article distributed under the terms of the Creative Commons Attribution License (CC BY 4.0), which permits unrestricted use, distribution, and reproduction in any medium, provided the original author and source are credited. 
distribution of intensely DAPI-stained heterochromatin, while $\mathrm{CMA}_{3}$ markings appeared on those terminal portions of the chromosomes corresponding to euchromatin. Similar to Ag-NOR, fluorescence in situ hybridization (FISH) with $18 \mathrm{~S}$ ribosomal DNA probe revealed distinct signals on the second pair of chromosomes. Microsatellite mapping $(\mathrm{GA})_{15}$ showed markings distributed in euchromatic regions, while mapping with $(\mathrm{CA})_{15}$ showed marking patterns in heterochromatic regions, together with a fully marked chromosome pair. Microsatellite hybridization, both in heterochromatic and euchromatic regions, may be related to the activity of transposable elements. These are capable of forming new microsatellites that can be dispersed and amplified in different regions of the genome, demonstrating that repetitive sequences can evolve rapidly, thus resulting in within-genus diversification.

\section{Keywords}

Cytogenetics, fluorescence in situ hybridization (FISH), heterochromatin, stingless bee

\section{Introduction}

Bees of the genus Melipona Illiger, 1806 are highly social insects, with collective offspring care, division into castes and one or more overlapping generations between adult colony members also within castes there are fully reproductive, poorly reproductive and sterile individuals (Wilson and Hölldobler 2005; Michener 2007). Members of the tribe Meliponini are commonly called stingless bees, and their species are distributed throughout the Neotropical region. The Meliponini tribe comprise 33 genera with approximately 417 known species (Camargo and Pedro 2013). Of these genera, Melipona is the most species-rich represented by 76 valid species, of which 43 occur in Brazil (Camargo and Pedro 2013; Pedro 2014).

With 23 species with described karyotypes, Melipona has the largest number of cytogenetically studied members (Tavares et al. 2017). According to karyotypic analyses, most species of the genus have a chromosome number of $2 \mathrm{n}=18$ (queens/workers) and $\mathrm{n}=9$ (drones). However, there are some exceptions. The species Melipona quinquefasciata Lepeletier, 1836 and M. rufiventris Lepeletier, 1836 which have B chromosomes (Rocha et al. 2007; Lopes et al. 2008), while M. seminigra merrillae Cockerell, 1919, M. seminigra pernigra Moure \& Kerr, 1950 and M. seminigra abunensis Cockerell, 1912 have $2 \mathrm{n}=22$ and $\mathrm{n}=11$ chromosomes (Francini et al. 2011; Andrade-Souza et al. 2018; Cunha et al. 2018). Melipona has a unique distribution pattern of constitutive heterochromatin $(\mathrm{CH})$, which differentiates it from other Meliponini (Hoshiba and Imai 1993; Rocha et al. 2003; Cunha et al. 2018). Based on the distribution pattern/quantity of $\mathrm{CH}$, species in the genus can be divided into two groups: Group $\mathrm{I}$ - composed of species with a low amount of $\mathrm{CH}$, present only in pericentromeric regions, and Group II - composed of species with a high amount of $\mathrm{CH}$, present along almost the entire length of each chromosome (Rocha and Pompolo 1998; Rocha et al. 2002; Lopes et al. 2011).

The objective of this study was to use a combination of classical cytogenetics and molecular tools to obtain information on the composition and organization of the chromatin of Melipona seminigra merrillae, an Amazonian stingless bee. 


\section{Material and methods}

Larvae of M. seminigra merrillae were collected in colonies maintained in the Instituto Nacional de Pesquisas da Amazônia (INPA) Meliponary, Manaus, Amazonas, Brazil. Mitotic chromosomes were obtained using the protocol given by Imai et al. (1988) with modifications: cerebral ganglia were removed from larvae in the post-defecation stage and dissected in $1 \%$ sodium citrate solution containing $0.005 \%$ colchicine. The cerebral ganglia were then dissected using entomological pins to expose cellular contents. The material containing metaphasic chromosomes were mounted on air-dried slides, which had been previously treated with three sequential fixatives: first (water: ethanol: acetic acid, 4:3:3), second (ethanol: acetic acid, 1:1), third (100\% acetic acid). Slides were then stained with 5\% Giemsa solution in Sörensen buffer (0.06 M, pH 6.8) for 20 minutes.

To analyze constitutive heterochromatin, slides with chromosome-bearing material were subjected to the C-banding technique, using Sumner's (1972) protocol with increased treatment time. Slides were treated in $0.2 \mathrm{M}$ hydrochloric acid $(\mathrm{HCl})$ solution for 6 minutes, washed in distilled water and incubated for 9 minutes in 5\% barium hydroxide solution freshly prepared, filtered and maintained at $60^{\circ} \mathrm{C}$. Barium hydroxide action was halted by immersing slides for 1 minute in $0.2 \mathrm{M} \mathrm{HCl}$ solution at room temperature. Slides were then incubated in $2 \mathrm{xSSC}$ solution (sodium chloride $0.3 \mathrm{M}$ and $0.03 \mathrm{M}$ trisodium citrate, $\mathrm{pH} 7.0$ ) in a water bath at $60{ }^{\circ} \mathrm{C}$ for 12 minutes, washed in running water and then stained with $5 \%$ Giemsa solution in Sörensen buffer (0.06 M, pH 6.8).

The active Nucleolus Organizer Regions (NORs) were detected with silver nitrate impregnation (Ag-NOR), following the protocol proposed by Howell and Black (1980). Sequential staining with fluorochromes chromomycin $\mathrm{A}_{3}\left(\mathrm{CMA}_{3}\right)$ and 4',6-diamidino-2-phenylindole (DAPI) was carried out following the methodology of Schweizer (1980).

Fluorescence in situ hybridization (FISH) was performed following Pinkel's et al. (1986) protocol. Products obtained via PCR (18S ribosomal DNA probe) were labeled by biotin-14-dATP nick translation (Biotin Nick Translation mix; Invitrogen) and digoxigenin 1-dUTP nick (Dig-Nick Translation mix; Roche Applied Science) following the manufacturer's instructions. This probe was obtained by PCR amplification using the primers 18SF1 (5'-GTCATATGTTGTCTCAAAGA-3') and 18SF2 (5' - TCT AAT TTT TTC AAA GAT AAC GC - 3') designed for Melipona quinquefasciata (Pereira 2006). The PCR reaction was performed in a thermocycler with a final volume of $20 \mu \mathrm{L}\left(2 \mu \mathrm{L}\right.$ of dye $10 \mathrm{X}+1.2 \mu \mathrm{L}$ of $\mathrm{MgCl}_{2} 25 \mathrm{mM}+0.2 \mu \mathrm{L}$ of dNTPs $+1 \mu \mathrm{L}$ of primer $18 \mathrm{SF} 1+1 \mu \mathrm{L}$ of primer $18 \mathrm{SF} 2+1 \mu \mathrm{L}$ of DNA template $+13.4 \mu \mathrm{L}$ of milli-Q water). The amplification cycle had the following steps: 3 minutes at $94^{\circ} \mathrm{C}$ (initial denaturation), 1 minute at $95^{\circ} \mathrm{C}$ (denaturation), 1 minute at $55^{\circ} \mathrm{C}$ (priming cycle), 2 minutes at $72{ }^{\circ} \mathrm{C}$ (extension), 5 minutes at $72{ }^{\circ} \mathrm{C}$ (final extension). The microsatellites (GA) ${ }_{15}$, $(\mathrm{CA})_{15}$ were labelled directly with Cy3 in the 5 ' regions (Sigma, St. Louis, MO, USA).

Images of metaphase chromosomes were captured with a Leica DM 2000 epifluorescence photomicroscope, using a 100× immersion objective. Slides stained with 
fluorochromes $\left(\mathrm{CMA}_{3}\right.$ and DAPI) were analyzed using $450-480 \mathrm{~nm}\left(\mathrm{CMA}_{3}\right)$ and 330-385 nm (DAPI) excitation filters. Adobe Photoshop 7.0 CS4 software was used to assemble karyotype images of mitotic metaphase chromosomes. Each chromosome was virtually cut and paired according to its size, following a decreasing order of size. In this study, 240 larvae were analyzed using 10 metaphases for each individual, and about 40 individuals produced satisfactory results.

\section{Results}

After analysis, we found that $M$. seminigra merrillae presented chromosomal numbers $2 \mathrm{n}=22$ and $\mathrm{n}=11$ (Fig. 1a, b). C-banding technique revealed a karyotype with a high heterochromatic content for all chromosomes, making it difficult to accurately visualize the position of the centromere. Therefore, the morphological identification was less precise or even impossible (Fig. 1c). Silver nitrate impregnation (Ag-NOR) in

a)
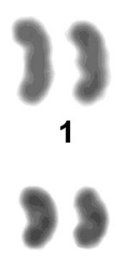

7

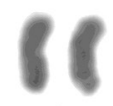

2

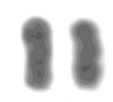

3

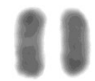

4

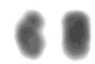

10

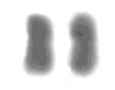

5

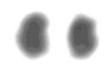

11

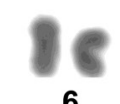

6

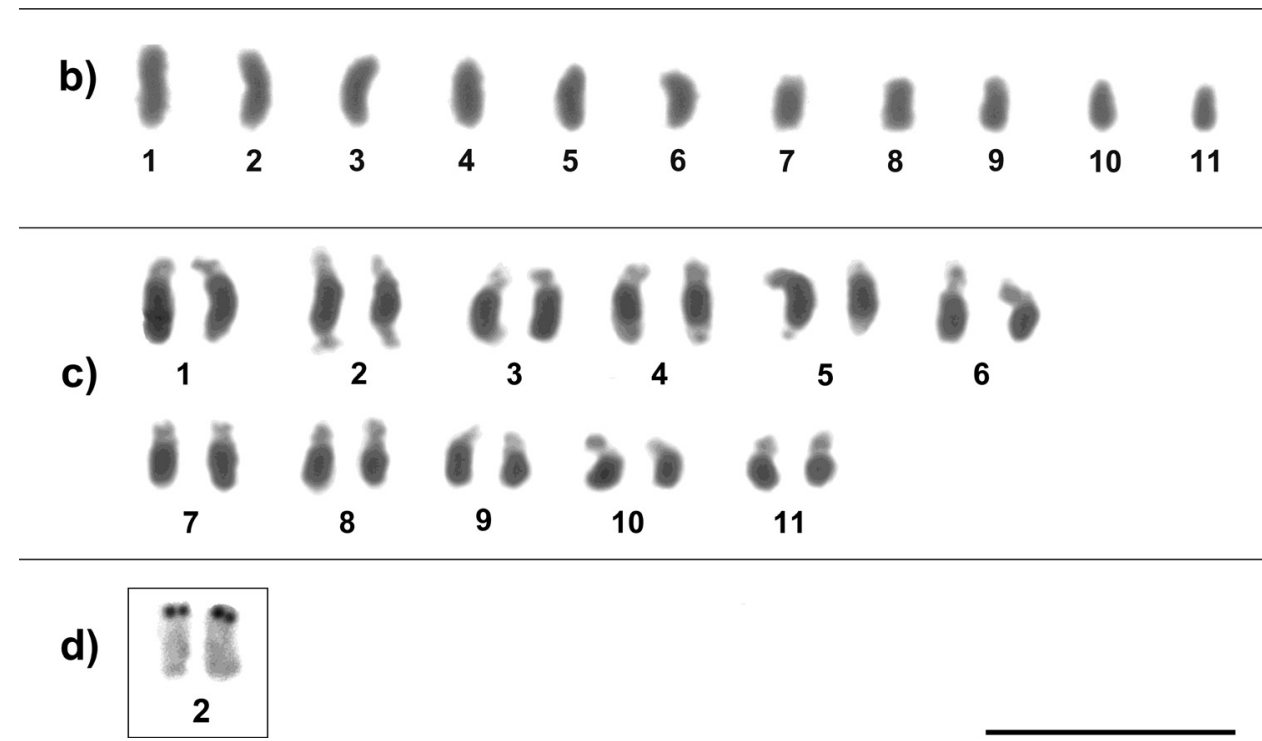

Figure I. Representative karyotype of Melipona seminigra merrillae with Giemsa-stained chromosomes a female karyotype with $2 \mathrm{n}=22$ b male karyotype with $\mathrm{n}=11$ c C-banding $\mathbf{d}$ Ag-NOR-banding of the second chromosome pair. Scale bar: $10 \mu \mathrm{m}$. 
M. seminigra merrillae showed transcriptionally active ribosomal sites on the second pair of chromosomes (Fig. 1d).

Regarding base-specific fluorophores, DAPI stained almost the entire length of all chromosomes evenly, except for the weakly stained terminal regions (Fig. 2a). In contrast, $\mathrm{CMA}_{3}$ marked terminal regions (Fig. 2b) $18 \mathrm{~S}$ ribosomal DNA sequence mapping showed two terminal markers on the second chromosomal pair, with a difference in size between homologues (Fig. 3).

The microsatellite probe (GA) ${ }_{15}$ labeled only euchromatic regions (Fig. 4a), while (CA) ${ }_{15}$ revealed signals spread almost along the entire length of all chromosomes except for terminal regions; however, a particular chromosome pair was fully labeled (Fig. 4b).
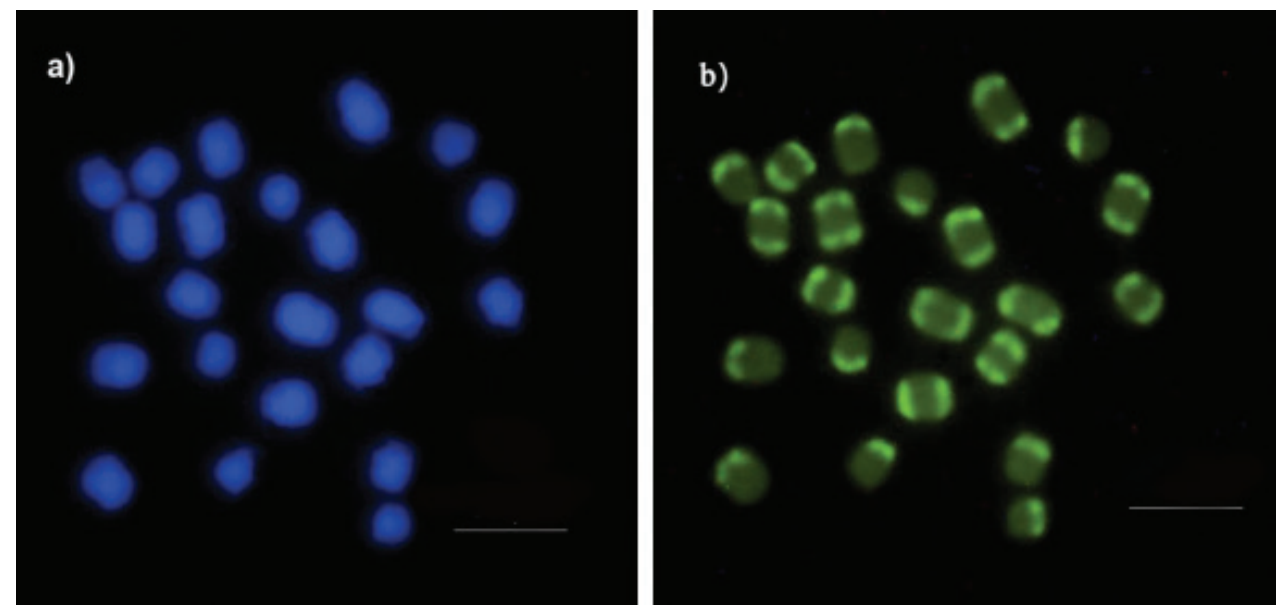

Figure 2. Fluorochrome staining of Melipona seminigra merrillae chromosomes a DAPI, with uniform staining on almost every chromosome $\mathbf{b} \mathrm{CMA}_{3}$, showing euchromatin in terminal regions of all chromosomes. Scale bars: $10 \mu \mathrm{m}$.

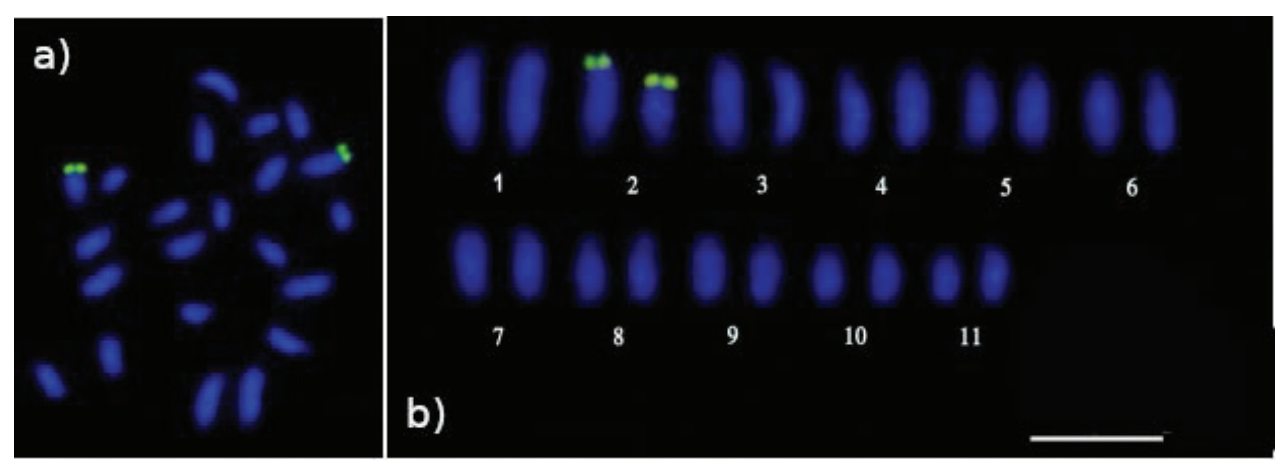

Figure 3. Distribution pattern of $18 \mathrm{~S} \mathrm{rDNA}$ sites on Melipona seminigra merrillae chromosomes. Additionally, size heteromorphism between homologues is also evident in the second pair a metaphase plate $\mathbf{b}$ karyotype with paired chromosomes. Scale bar: $10 \mu \mathrm{m}$. 


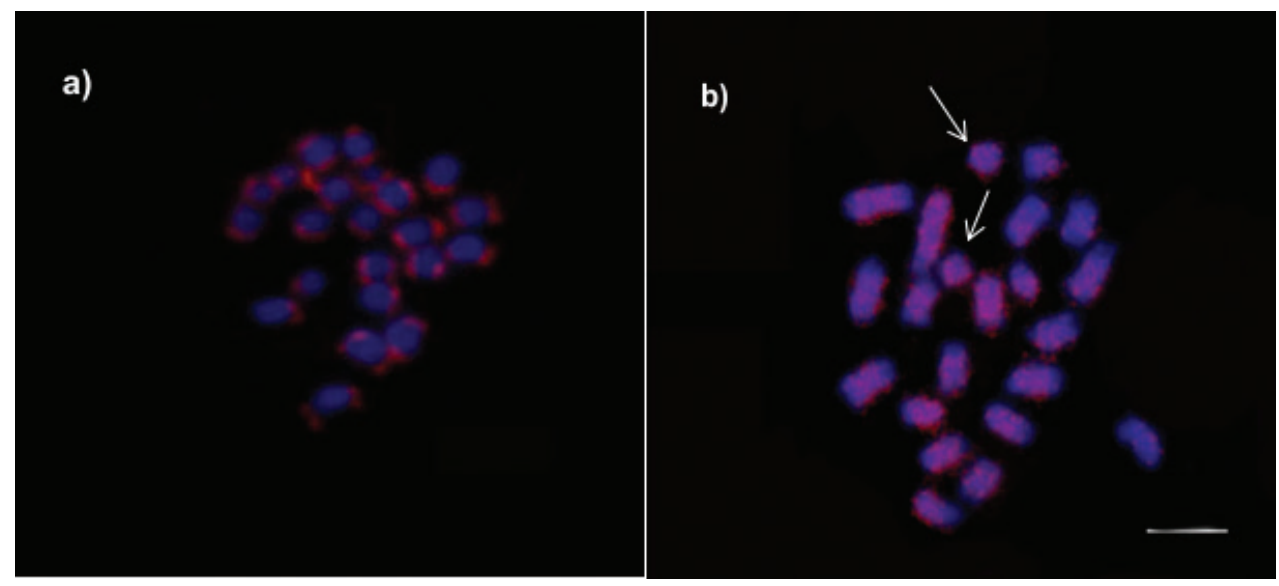

Figure 4. Repetitive DNA mapping on Melipona seminigra merrillae chromosomes a probe (GA) ${ }_{15}$ hybridized with euchromatic regions and $\mathbf{b}(\mathrm{CA})_{15}$ hybridized with heterochromatic regions. Arrows indicate fully marked chromosomes. Scale bar: $10 \mu \mathrm{m}$.

\section{Discussion}

Our findings confirm the observations of Francini et al. (2011) on the chromosome number of $M$. seminigra merrillae. Similar karyotype numbers have been reported for M. seminigra abunensis and M. seminigra pernigra (Andrade-Souza et al. 2018; Cunha et al. 2018). Such results differ from those already described for the genus, which generally has $2 \mathrm{n}=18$ and $\mathrm{n}=9$. Chromosome number variations have been also recorded for $M$. rufiventris and $M$. quinquefasciata; however, changes observed in these species were due to the presence of B chromosomes (Rocha et al. 2002; Capoco 2016; Tavares et al. 2017), which were not recorded in M. seminigra merrillae. Chromosome number increase in the studied species is due to centric fission with a subsequent addition of heterochromatin (Cunha et al. 2020).

Francini et al. (2011) classified M. seminigra merrillae as belonging to the low heterochromatic content group (group I) during previous cytogenetic studies. However, our analyses showed that this species has heterochromatin distributed almost throughout the entire length of chromosomes, with euchromatic regions restricted to the terminal regions. Consequently, the positions of the centromeres are difficult to determine, which supports the categorization of this species in the high heterochromatic content group (group II) (Rocha and Pompolo 1998; Rocha et al. 2002, 2003; Lopes et al. 2006, 2011; Cunha et al. 2018).

According to Tavares et al. (2010), the amount of heterochromatin in the different groups of Melipona is directly related to the size of the genome. Thus, group II species tend to have more genomic DNA than species in group I. The chromosome number of $M$. seminigra merrillae is higher $(2 \mathrm{n}=22)$. At present, we do not know whether this species has more DNA compared to those with $2 \mathrm{n}=18$ and the same heterochromatin distribution pattern. These aspects should be a subject of future investigations. 
The use of the Ag-NOR staining method to detect active NORs in Melipona normally does not show active sites, however, in $M$. seminigra merrillae it was possible to observe these regions which were clearly seen every time in the second chromosome pair. Similar results were also obtained for two other species, M. asilvai Moure, 1971 and M. marginata Lepeletier, 1836 (Maffei et al. 2001).

Results of chromosome staining by base-specific fluorophores in M. seminigra merrillae were similar to that described in a number of other Meliponini species belonging to group II (Rocha et al. 2003; Miranda et al. 2013; Andrade-Souza et al. 2018; Cunha et al. 2018). Several authors have suggested that $\mathrm{CMA}_{3}{ }^{+}$markings in Meliponini have a strong correlation with NORs (Rocha et al. 2007; Lopes et al. 2011; Lopes et al. 2012). Studies of the genus Melipona frequently report a chromosome pair strongly marked by $\mathrm{CMA}_{3}$. However, this was not the case in M. seminigra merrillae. Although the nucleolus organizing regions are characterized by rich concentration of CG bases, use of $\mathrm{CMA}_{3}$ demonstrates that, in this species, such regions do not always coincide, a fact also reported for other Meliponini (Duarte et al. 2009; Godoy et al. 2013).

Heteromorphism in size of a particular chromosome pair was found among all metaphases analyzed for homologous chromosomes by mapping $18 \mathrm{~S}$ rDNA sites. Apparently this is a recurrent characteristic in Meliponini (Rocha et al. 2007; Menezes et al. 2014; Andrade-Souza et al. 2018), and it is due to the repetitive nature of ribosomal DNAs, that results in errors during duplication of the genetic material or uneven crossing-over followed by deletion of a small part of the chromosome (Araújo et al. 2002; Mampumbu 2002).

In general, heterochromatic regions of chromosomes are characterized by large amounts of repetitive DNA (Cioffi et al. 2011). Although M. seminigra merrillae chromosomes carry large amounts of heterochromatin, the repetitive DNA probe (GA) ${ }_{15}$ hybridized with euchromatic regions, a pattern also observed in chromosome mapping of other Meliponini: in M. scutellaris Latreille, 1811 by Piccoli et al. (2018), and in M. interrupta Latreille, 1811 by Travenzoli et al. (2019a). This result may be associated with the presence of a family of satellite DNA or even with transposable elements (TEs) that could be linked to gene regulation. Among the bees, TEs have been reported for the genus Apis Linnaeus, 1758 (Lampe et al. 2003) and for some Melipona species (Cunha et al. 2020).

The presence of positive microsatellite $(\mathrm{CA})_{15}$ signals scattered along the chromosomes of $M$. seminigra merrillae is similar to the pattern revealed by $\mathrm{C}$-banding. Considering that microsatellites, or simple sequence repeats (SSRs), are notable components of constitutive heterochromatin, such repeats probably play an important role in chromosomal organization, regulation of gene expression, dissemination of heterochromatin and, in some cases, in increasing the size of the genome. These functions of SSRs have been demonstrated both for bees and other organisms (Cioffi et al. 2011; Milani and Cabral-de-Melo 2014; Biscotti et al. 2018; Cunha et al. 2020).

Our results indicate that the chromatin of $M$. seminigra merrillae has specific distribution patterns for each type of repeat, a characteristic that may be associated with the occurrence of chromosomal rearrangements in this species. Distribution of SSRs 
in heterochromatic and euchromatic regions in Melipona can also be explained by their relationship with transposable elements, which may have certain sites predisposed to the formation of new microsatellites. This would, in turn, favor dispersion and amplification of these microsatellites between different genomic regions (Milani and Cabralde-Mello 2014; Travenzoli et al. 2019b).

\section{Conclusions}

Considering the chromosome number and heterochromatic content, our results are similar to those already revealed for other subspecies of Melipona seminigra. As a result, the nature of the euchromatin, together with distribution of NOR sites and the $18 \mathrm{~S}$ rDNA, is similar to that in other species of Melipona that belong to the group II. This study also highlights the existence of possible chromosomal rearrangements in M. seminigra merrillae. Finally, use of the above-mentioned microsatellite probes for mapping repetitive DNA can expand our knowledge of this type of SSRs in Amazonian stingless bees in the future.

\section{Acknowledgements}

We would like to thank all staff members of INPA Bee Research Group (GPA), INPA Animal Genetics Laboratory (LGA), and Insect Cytogenetics Laboratory in Viçosa/MG. Adrian A. Barnett helped with the English. We also thank Instituto Nacional de Pesquisas da Amazônia - INPA for providing the working place with laboratories and meliponary for sampling the bees, and Coordenação de Aperfeiçoamento de Pessoal de Nível Superior - CAPES for providing the financial support for this study (funding code 001) and Governo do Estado do Amazonas, Secretaria de Estado de Desenvolvimento Econômico, Ciência, Tecnologia e Inovação (SEDECTI), Fundação de Amparo à Pesquisa do Estado do Amazonas (FAPEAM) - POSGRAD/scholarship for the financial support.

\section{References}

Andrade-Souza V, Duarte OMP, Martins CCC, Santos IS, Costa MGC, Costa MA (2018) Comparative molecular cytogenetics in Melipona Illiger species (Hymenoptera, Apidae). Sociobiology 65: 696-705. https://doi.org/10.13102/sociobiology.v65i4.3480

Araújo SMR, Pompolo SG, Perfectti F, Camacho JPM (2002) Genetic load caused by variation in the amount of rDNA in a wasp. Chromosome Research 10(7): 607-613. https://doi. org/10.1023/A:1020970820513

Biscotti MA, Barucca M, Canapa A (2018) New insights into the genome repetitive fraction of the Antarctic bivalve Adamussium colbecki. PLoS ONE 13: e0194502. https://doi. org/10.1371/journal.pone.0194502 
Camargo JMF, Pedro SRM (2013) Meliponini Lepeletier, 1836. In: Moure JS, Urban D, Melo GAR (Orgs) Catalogue of Bees (Hymenoptera, Apoidea) in the Neotropical Region - online version. http://moure.cria.org.br/catalogue [Accessed 11 May 2018]

Capoco MM (2016) Mapeamento de DNA repetitivo na abelha sem ferrão Tetragonisca fiebrigi (Schwarz, 1938) com ênfase nos cromossomos Bs. 2016. 34f. Dissertation of Master in Cellular and Structural Biology - Federal University of Viçosa, Viçosa. [In Portuguese]

Cioffi MB, Kejnovsky E, Bertollo LAC (2011) The chromosomal distribution of microsatellite repeats in the genome of the wolf fish Hoplias malabaricus, focusing on the sex chromosomes. Cytogenetic and Genome Research 132(4): 289-296. https://doi.org/10.1159/000322058

Cunha MS, Travenzoli NM, Ferreira RP, Cassinela EK, Silva H, Salomão TMF, Lopes DM (2018) Comparative cytogenetics in three Melipona species (Hymenoptera: Apidae) with two divergent heterochromatic patterns. Genetics and Molecular Biology 41(4): 806-813. https://doi.org/10.1590/1678-4685-gmb-2017-0330

Cunha MS, Campos LAO, Lopes DM (2020) Insights into the heterochromatin evolution in the genus Melipona (Apidae: Meliponini). Insectes Sociaux 67: 391-398. https://doi. org/10.1007/s00040-020-00773-6

Duarte OMP, Martins CCC, Waldschmidt AM, Costa MA (2009) Occurrence of multiple nucleolus organizer regions and intraspecific karyotype variation in Scaptotrigona xanthotricha Moure (Hymenoptera, Meliponini). Genetics and Molecular Research 8: 831-839. https://doi.org/10.4238/vol8-3gmr598

Francini IB, Gross MC, Nunes-Silva CG, Carvalho-Zilse GA (2011) Cytogenetic analysis of the Amazon stingless bee Melipona seminigra merrillae reveals different chromosome number for the genus. Scientia Agricola 68(5): 592-593. https://doi.org/10.1590/S010390162011000500012

Godoy DC, Ferreira RP, Lopes DM (2013) Chromosomal variation and cytogenetics of Plebeia lucii and P. phrynostoma (Hymenoptera: Apidae). Florida Entomologist 96: 1559-1566. https://doi.org/10.1653/024.096.0439

Hoshiba H, Imai HT (1993) Chromosome evolution of bees and wasps (Hymenoptera: Apocrita) on the basis of C-banding pattern analyses. Japanese Journal of Entomology 61: 465-492.

Howell WM, Black DA (1980) Controlled silver-staining of nucleolus organizer regions with a protective colloidal developer: a 1-step method. Experientia 36: 1014-1015. https://doi. org/10.1007/BF01953855

Imai HT, Taylor RW, Crosland MWJ, Crozier RH (1988) Modes of spontaneous evolution in ants with reference to the minimum interaction hypothesis. Japanese Journal of Genetics 63: 159-185. https://doi.org/10.1266/jjg.63.159

Lampe DJ, Witherspoon DJ, Soto-Adames FN, Robertson HM (2003) Recent horizontal transfer of mellifera subfamily mariner transposons into insect lineages representing four different orders shows that selection acts only during horizontal transfer. Molecular Biology and Evolution 20(4): 554-562. https://doi.org/10.1093/molbev/msg069

Lopes DM, Fernandes A, Campos LAO (2012) Cytogenetic of stingless bee Partamona rustica (Hymenoptera, Apidae). Anais do X Encontro sobre Abelhas. Ribeirão Preto, São Paulo, 324 pp. 
Lopes DM, Fernandes A, Praça-Fontes MM, Werneck HA, Resende HC, Campos LAO (2011) Cytogenetics of three Melipona species (Hymenoptera, Apidae, Meliponini). Sociobiology 58: $185-194$.

Lopes DM, Pompolo SG, Campos LAO, Tavares MG (2008) Cytogenetic characterization of Melipona rufiventris Lepeletier 1836 and Melipona mondury Smith 1863 (Hymenoptera, Apidae) by $\mathrm{C}$ banding and fluorochromes staining. Genetics and Molecular Biology 31: 49-52. https://doi.org/10.1590/S1415-47572008000100010

Lopes DM, Pompolo SG, Tavares MT, Campos LAO (2006) Caracterização citogenética de Melipona mondury Smith 1863 e Melipona rufiventris Lepeletier 1836 (Hymenoptera: Apidae) por banda $\mathrm{C}$ e fluorocromos. In: Congresso Brasileiro de Genética, 52. Foz do Iguaçu. Resumos. Foz do Iguaçu, SBG, 234 pp. [In Portuguese]

Maffei EMD, Pompolo SG, Silva-Júnior JC, Caixeiro APA, Rocha MP, Dergam JA (2001) Silver staining of nucleolar organizer regions (NOR) in some species of Hymenoptera (bees and parasitic wasps) and Coleoptera (lady-beetle). Cytobios 104: 119-125.

Mampumbu AR (2002) Análise citogenética da heterocromatina e da NOR em populaçóes de abelhas sem ferrão Friesella schrottkyi (Friese, 1900) (Hymenoptera: Apidae: Meliponini). Master's Thesis, State University of Campinas. [In Portuguese]

Menezes RST, Carvalho AF, Correia JPSO, Silva TS, Somavilla A, Costa MA (2014) Evolutionary trends in the chromosome numbers of swarm-founding social wasps. Insectes Sociaux 61(4): 385-393. https://doi.org/10.1007/s00040-014-0365-3

Michener CD (2007) The bees of the world ( $2^{\text {nd }}$ ed.). The John Hopkins University Press, Baltimore, $953 \mathrm{pp}$.

Milani D, Cabral-de-Mello DC (2014) Microsatellite organization in the grasshopper Abracris flavolineata (Orthoptera: Acrididae) revealed by FISH mapping: remarkable spreading in the A and B chromosomes. PLoS ONE 9(5): e97956. https://doi.org/10.1371/journal. pone.0097956

Miranda RV, Fernandes A, Lopes DM (2013) Karyotype description of Cephalotrigona femorata Smith (Hymenoptera: Apidae) and the C-banding pattern as a specific marker for Cephalotrigona. Sociobiology 60: 131-134. https://doi.org/10.13102/sociobiology.v60i1.125-127 Pedro SRM (2014) The stingless bee fauna in Brazil (Hymenoptera: Apidae). Sociobiology 61: 348-354. https://doi.org/10.13102/sociobiology.v61i4.348-354

Pereira JOP (2006) Diversidade genética da abelha sem ferrão Melipona quinquefasciata baseada no seqüenciamento das regióes ITS1 parcial e $18 \mathrm{~S}$ do DNA ribossômico nuclear. PhD Thesis. Universidade Federal do Ceará, Fortaleza, Ceará, 142 pp. [In Portuguese] http://www. repositorio.ufc.br/handle/riufc/17038 [Accessed 11 May 2018]

Piccoli MCA, Bardella VB, Cabral-de-Mello DC (2018) Repetitive DNAs in Melipona scutellaris (Hymenoptera: Apidae: Meliponidae): Chromosomal distribution and test of multiple heterochromatin amplification in the genus. Apidologie 49: 497-504. https://doi. org/10.1007/s13592-018-0577-z

Pinkel D, Straume T, Gray JW (1986) Cytogenetic analysis using quantitative, high-sensitivity, fluorescence hybridization. Proceedings of the Natural Academy of Sciences 83: 2934 2938. https://doi.org/10.1073/pnas.83.9.2934 
Rocha MP, Pompolo SG, Fernandes A, Campos LAO (2007) Melipona-seis décadas de citogenética. Bioscience Journal 23: 111-117. [In Portuguese] http://www.seer.ufu.br/index. php/biosciencejournal/article/view/6839

Rocha MP, Pompolo SG, Campos LAO (2003) Citogenética da tribo Meliponini (Hymenoptera, Apidae). In: Melo GAR, Santos IA (Eds) Apoidea Neotropica: homenagem aos 90 anos de Jesus Santiago Moure. Criciúma, 311-320. [In Portuguese]

Rocha MP, Pompolo SG, Dergam JA, Fernandes A, Campos LAO (2002) DNA characterization and karyotypic evolution in the genus Melipona (Hymenoptera Meliponini). Hereditas 136: 19-27. https://doi.org/10.1034/j.1601-5223.2002.1360104.x

Rocha MP, Pompolo SG (1998) Karyotypes and heterochromatin variation (C-bands) in Melipona species (Hymenoptera, Apidae, Meliponinae). Genetics and Molecular Biology 21: 41-45. https://doi.org/10.1590/S1415-47571998000100008

Schweizer D (1980) Simultaneous fluorescent staining of R bands and specific heterochromatic regions (DA/DAPI-bands) in human chromosomes. Cytogenetics and Cell Genetics 27: 190-193. https://doi.org/10.1159/000131482

Sumner AT (1972) A simple technique for demonstrating centromeric heterochromatin. Experimental Cell Research 75: 304-306. https://doi.org/10.1016/0014-4827(72)90558-7

Tavares MG, Lopes DM, Campos LAO (2017) An overview of cytogenetics of the tribe Meliponini (Hymenoptera: Apidae). Genetica 145: 241-258. https://doi.org/10.1007/ s10709-017-9961-2

Tavares MG, Carvalho CR, Soares FAF (2010) Genome size variation in Melipona species (Hymenoptera: Apidae) and sub-grouping by their DNA content. Apidologie 41: 636-642. https://doi.org/10.1051/apido/20010023

Travenzoli NM, Barbosa IC de O, Carvalho-Zilse GA, Salomão TMF, Lopes DM (2019a) Karyotypic description and repetitive DNA chromosome mapping of Melipona interrupta Latreille, 1811 (Hymenoptera: Meliponini). Caryologia. International Journal of Cytology, Cytosystematics and Cytogenetics 72(2): 91-95. https://doi.org/10.13128/cayologia-239

Travenzoli NM, Lima BA, Cardoso DC, Dergam JA, Fernandes-Salomão TM, Lopes DM (2019b) Cytogenetic Analysis and Chromosomal Mapping of Repetitive DNA in Melipona Species (Hymenoptera, Meliponini). Cytogenetic and Genome Research 158(4): 213-224. https://doi.org/10.1159/000501754

Wilson EO, Hölldobler B (2005) Eusociality: origin and consequences. Proceedings of the Natural Academy of Sciences 102: 13367-13371. https://doi.org/10.1073/pnas.0505858102 